\title{
Inverse association of plasma IL-I 3 and inflammatory chemokines with lung function impairment in stable COPD: a cross-sectional cohort study
}

Janet S Lee*1, Matthew R Rosengart ${ }^{2}$, Venkateswarlu Kondragunta ${ }^{3}$, Yingze Zhang ${ }^{1}$, Jessica McMurray ${ }^{1}$, Robert A Branch ${ }^{2}$, Augustine MK Choi ${ }^{1}$ and Frank C Sciurba ${ }^{1}$

Address: ${ }^{1}$ Division of Pulmonary, Allergy, and Critical Care Medicine, Department of Medicine, University of Pittsburgh, Pittsburgh, PA, 15213, USA, ${ }^{2}$ Division of Trauma/General Surgery, Department of Surgery, University of Pittsburgh, Pittsburgh, PA, 15213, USA and ${ }^{3}$ Division of Clinical Pharmacology, Department of Medicine, University of Pittsburgh, Pittsburgh, PA, 15213, USA

Email: Janet S Lee* - leejs3@upmc.edu; Matthew R Rosengart - rosengartmr@upmc.edu; Venkateswarlu Kondragunta - vk12@duke.edu; Yingze Zhang - zhangy@upmc.edu; Jessica McMurray - mcmurrayjm@upmc.edu; Robert A Branch - Branch@dom.pitt.edu;

Augustine MK Choi - choiam@upmc.edu; Frank C Sciurba - sciurbafc@upmc.edu

* Corresponding author

Published: 14 September 2007

Respiratory Research 2007, 8:64 doi:10.1 I86/1465-992I-8-64

This article is available from: http://respiratory-research.com/content/8/1/64

(c) 2007 Lee et al; licensee BioMed Central Ltd.

This is an Open Access article distributed under the terms of the Creative Commons Attribution License (http://creativecommons.org/licenses/by/2.0), which permits unrestricted use, distribution, and reproduction in any medium, provided the original work is properly cited.
Received: II May 2007

Accepted: 14 September 2007

\begin{abstract}
Background: Chronic obstructive pulmonary disease (COPD) is a heterogeneous syndrome characterized by varying degrees of airflow limitation and diffusion impairment. There is increasing evidence to suggest that COPD is also characterized by systemic inflammation. The primary goal of this study was to identify soluble proteins in plasma that associate with the severity of airflow limitation in a COPD cohort with stable disease. A secondary goal was to assess whether unique markers associate with diffusion impairment, based on diffusion capacity of carbon monoxide (DLCO), independent of the forced expiratory volume in I second $\left(\mathrm{FEV}_{1}\right)$.

Methods: A cross sectional study of 73 COPD subjects was performed in order to examine the association of 25 different plasma proteins with the severity of lung function impairment, as defined by the baseline measurements of the \% predicted $\mathrm{FEV}_{1}$ and the \% predicted DLCO. Plasma protein concentrations were assayed using multiplexed immunobead-based cytokine profiling. Associations between lung function and protein concentrations were adjusted for age, gender, pack years smoking history, current smoking, inhaled corticosteroid use, systemic corticosteroid use and statin use.
\end{abstract}

Results: Plasma concentrations of CCL2/monocyte chemoattractant protein-I (CCL2/MCP-I), CCL4/ macrophage inflammatory protein-I $\beta$ (CCL4/MIP - I $\beta$ ), CCLI I/eotaxin, and interleukin-I3 (IL-I3) were inversely associated with the \% FEV . Plasma concentrations of soluble Fas were associated with the \% DLCO, whereas CXCL9/monokine induced by interferon- $\gamma$ (CXCL9/Mig), granulocyte- colony stimulating factor (G-CSF) and IL13 showed inverse relationships with the \% DLCO.

Conclusion: Systemic inflammation in a COPD cohort is characterized by cytokines implicated in inflammatory cell recruitment and airway remodeling. Plasma concentrations of IL- 13 and chemoattractants for monocytes, T lymphocytes, and eosinophils show associations with increasing severity of disease. Soluble Fas, G-CSF and CXCL9/Mig may be unique markers that associate with disease characterized by disproportionate abnormalities in $\mathrm{DLCO}$ independent of the $\mathrm{FEV}$. 


\section{Background}

Chronic obstructive pulmonary disease (COPD), while defined by the presence of incompletely reversible airflow obstruction, represents a syndrome of various physiologic impairments [1,2]. COPD is also defined by "an abnormal inflammatory response to noxious stimuli" $[1,2]$, and increasing evidence suggests that COPD is a disease characterized by both local and systemic inflammation [3].

The best characterized systemic marker is C-reactive protein (CRP) [3,4], but its lack of specificity provides little insight into potential mechanisms underlying the systemic inflammation characterizing COPD. We hypothesize that this systemic inflammation may be further characterized by examining associations between physiologic indices of lung function impairment and members of various classes of soluble proteins. To date, studies examining the association between a wide range of soluble proteins in plasma and severity of lung function impairment during stable COPD are lacking. This is due, in part, to the limited amount of sample that can be obtained from subjects at any given time.

We conducted an exploratory analysis to determine the associations between increasing physiologic severity of COPD, as defined by the \% predicted $\mathrm{FEV}_{1}$ or $\%$ DLCO, during stable disease and plasma concentrations of 25 different cytokines and growth factors. We adjusted for current cigarette smoking and corticosteroid use because others have shown that these factors may be potential modifiers of systemic inflammation in this cohort [5-7]. We also adjusted for variables such as gender, age, statin use, and pack years smoking that may influence cytokine levels. This analysis represents an important, initial stage in identifying candidate plasma proteins for future prospective, longitudinal studies and one that utilizes a new technique to assay for multiple cytokines at a given time.

\section{Methods}

\section{Patient selection}

Seventy-three individuals enrolled in the Emphysema/ COPD Research Center (ECRC) of the University of Pittsburgh gave informed consent for the study. Inclusion criteria included clinically stable COPD at the time of the examination, tobacco exposure of at least 10 pack years, and no clinical diagnosis of rheumatologic, infectious or other systemic inflammatory disease. Exclusion criteria included dominant restrictive spirometric impairment, a significant allergic history, completely reversible airflow obstruction or a history of clinical asthma. The study was approved by the University of Pittsburgh Institutional Review Board.

\section{Pulmonary function measurements}

Spirometry was performed on 73 subjects using standard methodology at the time of entry into the study [8-10]. Fifty-three subjects also had single breath carbon monoxide diffusing capacity using standard methodology [11]. Standard reference equations for $\% \mathrm{FEV}_{1}$ and \% DLCO were used $[12,13]$.

\section{Plasma marker measurements}

Plasma samples were obtained from subjects upon enrollment into the ECRC registry. Blood was collected into acid citrate dextrose (ACD) cell preparation tubes (CPT tubes). Samples were processed immediately, and plasma was isolated and stored immediately at $-80^{\circ} \mathrm{C}$ until analyzed. A detailed methods of the multiplex assay performed at the University of Pittsburgh Cancer Institute Luminex Core Facility has been previously described [14]. We have previously used a multiplex immuno-bead assay system (Luminex, Austin, TX, USA) to assay multiple systemic cytokine concentrations using both mouse and human plasma samples [15]. Reproducibility of cytokine signals for inter-individual comparisons using stimulated plasma samples has been previously demonstrated using the multiplex format [16]. Four sets of plates were used to assay a total of 28 cytokines and inflammatory markers: Set 1 ) Twenty-three cytokines in multiplex format (Biosource Invitrogen, Camarillo, CA); Set 2) EGFR, Fas, and FasL analytes in multiplex format (University of Pittsburgh Luminex Core Facility, Pittsburgh, PA); Set 3) CRP concentrations (LINCO Research, St. Charles, Missouri); Set 4) MPO concentrations (LINCO Research, St. Charles, Missouri). All samples were assayed simultaneously to minimize day-to-day variability (Table 1 ).

Selection of specific cytokines in the study was based upon two main criteria: (1) availability of reagent using the Luminex platform, and (2) prior published data to suggest biological plausibility of a cytokine or soluble protein in either systemic or local inflammation observed in COPD. We chose six broad classes of soluble proteins and measured representative markers (Table 1). Apoptosis-related proteins included soluble Fas, FasL, soluble TNFRI and TNFRII [17-19]. Acute phase reactants included C-reactive protein (CRP) [4] and Myeloperoxidase (MPO) [20]. Representative chemokines included CCL2/MCP-1, CCL3/MIP-1 $\alpha$ and CCL4/MIP-1 $\beta$ [21], CCL5/RANTES [22], CCL11/eotaxin [23], CXCL8/IL-8 [24,25], and CXCL9/Mig [26]. $\mathrm{T}_{\mathrm{H}}$ related cytokines were also of considerable interest, given recent findings regarding the role of the $\mathrm{T}_{\mathrm{H}}$ phenotype in COPD [27-29]. Representative $\mathrm{T}_{\mathrm{H} 1}$ and $\mathrm{T}_{\mathrm{H} 2}$ cytokines interferon-gamma (IFN$\gamma)$, interleukin-2 (IL-2) and its soluble receptor IL-2R, interleukin-4 (IL-4), and IL-13 were chosen on this basis. Inflammation related proteins included TNF- $\alpha[30,31]$, soluble TNFR1 and TNFRII [30,31], IL-1 $\beta$ [32], IL-6 [32], 
and IL-10 [28]. Growth factors included epidermal growth factor (EGF) and its soluble receptor epidermal growth factor receptor (EGFR) [33-35], fibroblast growth factor beta (FGFß) $[36,37]$, granulocyte-colony stimulating factor (G-CSF)[38], hepatocyte growth factor (HGF) [39], and vascular endothelial growth factor (VEGF) [40].

Standard curves were generated according to the manufacturer's instructions. Goodness of fit for standard curves was determined by the standards recovery method and performed by calculating the following equation for the concentration of each standard: (observed concentration/ expected concentration) $\times 100$. Concentrations for the unknown samples were calculated based upon a 5 parametric curve fitting program (Bio-Rad Laboratories, Hercules, CA). The 5 parametric curve fitting program yields extrapolated values beyond the concentrations for a given standard curve as determined by conventional linear regression, and is the preferred mathematical modeling for multiplex immunoassays $[41,42]$. This provided a greater detectable range of observed concentrations, and was particularly useful for analytes where plasma concentrations of samples were uniformly low.

We defined the lower limit of detection (LLD) for each analyte as the lowest observed concentration in $\mathrm{pg} / \mathrm{mL}$. This was, in some instances, an extrapolated value that was lower than the lowest standard curve concentration. Unknown sample concentrations, below the LLD for a given analyte, were assigned a value set just below the LLD using the following equation: undetectable value = LLD of analyte/squared root 2 . This method of assigning a value for unknown sample concentrations with undetectable levels has been previously used to examine the relationship of impaired lung function to circulating levels of Creactive protein and fibrinogen [4]. This allowed for the inclusion of all samples in our analysis, with data shown in Table 1.

\section{Statistical analysis}

We performed univariate and multivariate linear regression analysis to test the association between the concentration of each plasma cytokine and the physiologic indices of interest: percent (\%) predicted $\mathrm{FEV}_{1}$ and the $\%$ predicted DLCO. The dependent variable of interest, plasma cytokine concentration, was not normally distributed; thus, values were log transformed to meet the assumption of normality for linear regression. Standard regression diagnostics were performed to ensure the assumptions for linear regression were met. Covariates previously published as associated with the outcomes of interest (e.g. current smoking and corticosteroid use) were identified $a$ priori and also included [5-7]. We also included variables presumed to alter cytokine values: age, gender, statin use, and pack year smoking history. Statisti-
Table I: Detectability of plasma marker concentrations

\begin{tabular}{|c|c|c|c|c|}
\hline Classification & $\begin{array}{l}\text { Plasma } \\
\text { marker }\end{array}$ & $\begin{array}{l}\text { Mean }(\mathrm{pg} / \mathrm{mL}) \\
+\mathrm{SE}\end{array}$ & $\begin{array}{l}\text { LLD* } \\
(\mathrm{pg} / \mathrm{mL})\end{array}$ & $\begin{array}{l}\text { below } \\
\text { LLD (\%) }\end{array}$ \\
\hline \multirow[t]{2}{*}{ Apoptosis } & Fas & $74 \pm 3$ & 1.3 & 0 \\
\hline & FasL & $68 \pm 4$ & 6.5 & 0 \\
\hline \multirow[t]{2}{*}{ Acute phase } & CRP & $\begin{array}{c}6268332 \pm \\
1 / 24813\end{array}$ & 78 & 0 \\
\hline & MPO & $4381 \pm 589$ & 13 & 3 \\
\hline \multirow[t]{7}{*}{ Chemokines } & $\begin{array}{l}\text { CCL2/ } \\
\text { MCP - I }\end{array}$ & $202 \pm 6$ & 10 & 0 \\
\hline & $\begin{array}{l}\text { CCL3/ } \\
\text { MIP-I } \alpha\end{array}$ & $161 \pm 33$ & 6.8 & 5 \\
\hline & $\begin{array}{l}\text { CCL4/ } \\
\text { MIP-I } \beta\end{array}$ & $115 \pm 20$ & 1.3 & 1 \\
\hline & $\begin{array}{l}\text { CCL5/ } \\
\text { RANTES }\end{array}$ & $5249 \pm 398$ & 8.2 & 0 \\
\hline & $\begin{array}{l}\text { CCLII/ } \\
\text { eotaxin }\end{array}$ & $76 \pm 3$ & 2.3 & 0 \\
\hline & $\begin{array}{l}\text { CXCL8/ } \\
\text { IL-8 }\end{array}$ & $\mathrm{II} \pm 0.4$ & 6.1 & 0 \\
\hline & $\begin{array}{l}\text { CXCL9/ } \\
\text { Mig }\end{array}$ & $1163 \pm 87$ & 35 & 0 \\
\hline \multirow{5}{*}{$\begin{array}{l}T_{H} \text { Related } \\
\text { Cytokines }\end{array}$} & IFN- $\gamma$ & $55 \pm 7$ & 2.1 & 8 \\
\hline & $\mathrm{IL}-2$ & $103 \pm 23$ & 2.6 & 23 \\
\hline & $\mathrm{IL}-2 \mathrm{R}+$ & $344 \pm 28$ & 39 & 0 \\
\hline & $\mathrm{IL}-4$ & $15 \pm 3$ & 0.6 & 25 \\
\hline & IL-13 & $98 \pm 7$ & 8.2 & 11 \\
\hline \multirow[t]{6}{*}{ Inflammation } & TNF- $\alpha$ & $55 \pm 7$ & 5.3 & 0 \\
\hline & TNFRI $\dagger$ & $1352 \pm 95$ & 36 & 0 \\
\hline & TNFRII† & $3231 \pm 138$ & 39 & 0 \\
\hline & IL-I $\beta$ & $72 \pm 17$ & 8.5 & 45 \\
\hline & IL-6 & $19 \pm 4$ & 0.4 & 1 \\
\hline & IL-10 & $0.3 \pm 0.08$ & 0.2 & 96 \\
\hline \multirow{6}{*}{$\begin{array}{l}\text { Growth } \\
\text { Factors }\end{array}$} & EGF & $19 \pm 1.5$ & 2.5 & 0 \\
\hline & EGFR $\dagger$ & $19769 \pm 434$ & 13.5 & 0 \\
\hline & $\mathrm{FGF} \beta$ & $\mathrm{NE} \ddagger$ & $\mathrm{NE} \ddagger$ & $\mathrm{NE}^{\ddagger}$ \\
\hline & G-CSF & $2496 \pm 180$ & 379 & 0 \\
\hline & HGF & $196 \pm 9$ & 2.8 & 0 \\
\hline & VEGF & NE $\ddagger$ & $N E \ddagger$ & $N E^{\ddagger}$ \\
\hline
\end{tabular}

*LLD, Lower Limit of Detection

tFor clarity, the soluble receptors are grouped with their respective ligand

$\neq N E$, Not Evaluable

cal significance was determined at a p-value $<0.05$. We did not attempt to adjust for multiple comparisons as our emphasis, being exploratory, was to minimize a Type I error and any adjustment could potentially miss real differences within the scope of this modest sample size [43]. SAS 8.2 (SAS Institute Inc., Cary, NC) and STATA 9.0 (Stata Corporation, College Station, Texas) softwares were used for analysis.

\section{Results \\ Subject demographics}

Seventy-three individuals were recruited for analysis. Table 2 shows the subject demographics for each Global 
Table 2: Demographics, comparison of subjects by GOLD classification

\begin{tabular}{|c|c|c|c|c|c|c|}
\hline & GOLD 0 & GOLD I & GOLD 2 & GOLD 3 & GOLD 4 & Total \\
\hline Sample size & 5 & 8 & 21 & 20 & 19 & 73 \\
\hline Age, years* & $61(2)$ & $59(2)$ & $64(2)$ & $67(2)$ & $60(2)$ & $63(1)$ \\
\hline Sex, M/F & $3 / 2$ & $5 / 3$ & $12 / 9$ & $13 / 7$ & $9 / 10$ & $42 / 31$ \\
\hline Pack years* & $37(4)$ & $57(8)$ & $60(7)$ & $53(4)$ & $47(4)$ & $53(3)$ \\
\hline $\begin{array}{l}\text { Current smokers } \\
\text { (\%) }\end{array}$ & $2(40)$ & $4(50)$ & $7(33)$ & $5(25)$ & I (5) & $19(26)$ \\
\hline ICS use (\%) & $0(0)$ & I (I3) & $7(33)$ & $12(60)$ & $16(84)$ & $36(49)$ \\
\hline SCS use (\%) & $0(0)$ & $0(0)$ & $0(0)$ & $2(10)$ & $3(16)$ & $5(7)$ \\
\hline$\% \mathrm{FEV}_{1} *$ & $87(4)$ & $91(3)$ & $66(2)$ & $39(I)$ & $21(1)$ & $51(3)$ \\
\hline $\mathrm{FEV}_{1} / \mathrm{FVC}^{*}$ & $77(2)$ & $63(2)$ & $55(2)$ & $37(2)$ & $28(1)$ & $45(2)$ \\
\hline$\%$ DLCO* $\dagger$ & $68(4)$ & $58(7)$ & $62(4)$ & $37(2)$ & $25(I)$ & $46(3)$ \\
\hline
\end{tabular}

ICS, inhaled corticosteroids; SCS, systemic corticosteroids

*Data are presented as mean (SEM)

tDLCO \% predicted measurements not available for I subject in GOLD 0, 2 subjects in GOLD I, 6 subjects in GOLD 2, 6 subjects in GOLD 3, 5 subjects in GOLD 4.

initiative for Chronic Obstructive Lung Disease (GOLD) classification. The prevalence of cigarette smoking decreased and the use of inhaled or systemic corticosteroids increased with more severe airflow obstruction.

Fifty-three of the 73 individuals from the cohort received DLCO measurements (Table 3). We addressed the potential for selection bias by comparing the patient characteristics of those with and without DLCO measurements. There was no significant difference between those with and those without DLCO measurements for any of the patient characteristics.

\section{Detectability of plasma protein concentrations}

Twenty-eight markers from 6 classes of soluble proteins were originally measured. The mean plasma concentrations in $\mathrm{pg} / \mathrm{mL}$ are depicted in Table 1 . Sixteen of 28 proteins showed detectable concentrations for all samples (Table 1). Ten of 28 proteins were below the detectable range for some samples (MPO, CCL3/MIP-1 $\alpha$, CCL4/ MIP-1 $\beta$, IFN- $\gamma$, IL-2, IL-4, IL-13, IL-1 $\beta$, IL-6, IL-10). None of the samples were above the detectable range for any of the proteins measured. IL-10 concentrations were undetectable in virtually all patients $(70 / 73,96 \%)$, and standard curves generated for FGF $\beta$ and VEGF were consistently poor. Thus, IL-10, FGF $\beta$, and VEGF were excluded from further analysis, and a total of 25 cytokines were assessed for an association with severity of lung function impairment.

\section{Association between systemic cytokines and FEVI}

In univariate analyses, increasing concentrations of $\mathrm{T}$ helper $\left(\mathrm{T}_{\mathrm{H}}\right)$ related cytokines interferon- $\gamma($ IFN- $\gamma)$, interleukin-2 (IL-2), interleukin-4 (IL-4) and IL-13 were associated with increasing severity of airflow obstruction, as characterized by decreasing \% predicted $\mathrm{FEV}_{1}$ (Table 4). Increasing concentration of the monocyte and $\mathrm{T}$ lym- phocyte chemokine CCL4/MIP-1 $\beta$ was also associated with increasing severity of airflow obstruction (Table 4).

We did not observe significant associations between plasma CRP concentrations and the $\%$ predicted $\mathrm{FEV}_{1}$. We explored the effect of inhaled corticosteroids on the relationship between CRP and the $\% \mathrm{FEV}_{1}$ because of previous findings that inhaled corticosteroids can suppress systemic CRP levels [6]. In contrast to other cytokines examined, we noted interaction between corticosteroids with CRP concentrations $(\mathrm{p}=0.05)$. An overall association was not observed between increasing plasma CRP with increasing severity of airflow limitation because the magnitude of the difference in CRP concentration across \% $\mathrm{FEV}_{1}$ was diminished in those with corticosteroid use as compared to those without (data not shown).

\section{Multivariate model of the association between systemic cytokines and FEV,}

After adjusting for age, gender, pack years smoking history, current smoking, inhaled corticosteroid use, sys-

Table 3: Demographics, comparison of subjects with and without \% DLCO measurements

\begin{tabular}{llll}
\hline & $\begin{array}{l}\text { Subjects with } \\
\text { DLCO }\end{array}$ & $\begin{array}{l}\text { Subjects } \\
\text { without DLCO }\end{array}$ & P-value \\
\hline Sample size & 53 & 20 & - \\
Age, years* & $64(1)$ & $61(2)$ & 0.16 \\
Sex, M/F & $32 / 21$ & $10 / 10$ & 0.43 \\
Pack years* & $54(3)$ & $49(5)$ & 0.49 \\
Current & $15(28)$ & $4(20)$ & 0.48 \\
smokers (\%) & & & \\
ICS use (\%) & $24(45)$ & $12(60)$ & 0.27 \\
SCS use (\%) & $3(6)$ & $2(10)$ & 0.52 \\
$\%$ FEV $*$ & $5 I(4)$ & $51(6)$ & 0.97 \\
FEV,/FVC* & $45(2)$ & $46(4)$ & 0.89 \\
\hline
\end{tabular}

*Data are presented as mean (SEM). 
Table 4: Association between plasma marker concentrations and \% FEVI, unadjusted

\begin{tabular}{|c|c|c|c|c|}
\hline Classification & $\begin{array}{l}\text { Plasma } \\
\text { marker }\end{array}$ & $\beta^{\dagger}$ & $95 \% \mathrm{Cl}$ & $\mathrm{P}^{\ddagger}$ \\
\hline \multirow[t]{2}{*}{ Apoptosis } & Fas & 0.003 & $-0.00 \mathrm{I}, 0.0 \mathrm{I}$ & 0.12 \\
\hline & FasL & 0.001 & $-0.004,0.01$ & 0.67 \\
\hline \multirow[t]{2}{*}{ Acute phase } & CRP & -0.01 & $-0.02,0.003$ & 0.19 \\
\hline & MPO & 0.0004 & $-0.01,0.01$ & 0.93 \\
\hline \multirow[t]{7}{*}{ Chemokines } & $\begin{array}{l}\text { CCL2/ } \\
\text { MCP - I }\end{array}$ & -0.002 & $-0.004,0.001$ & 0.14 \\
\hline & $\begin{array}{l}\text { CCL3/ } \\
\text { MIP-I } \alpha\end{array}$ & -0.004 & $-0.02,0.01$ & 0.53 \\
\hline & $\begin{array}{l}\text { CCL4/ } \\
\text { MIP-I } \beta\end{array}$ & -0.01 & $-0.02,-0.003$ & $\begin{array}{l}< \\
0.01\end{array}$ \\
\hline & $\begin{array}{l}\text { CCL5/ } \\
\text { RANTES }\end{array}$ & -0.005 & $-0.01,0.002$ & 0.18 \\
\hline & $\begin{array}{l}\text { CCLII/ } \\
\text { eotaxin }\end{array}$ & -0.003 & $-0.006,0.0004$ & 0.09 \\
\hline & $\begin{array}{l}\text { CXCL8/ } \\
\text { IL-8 }\end{array}$ & -0.002 & $-0.01,0.001$ & 0.18 \\
\hline & $\begin{array}{l}\text { CXCL9/ } \\
\text { Mig }\end{array}$ & -0.01 & $-0.01,0.001$ & 0.09 \\
\hline \multirow{5}{*}{$\begin{array}{l}T_{\mathrm{H}} \text { Related } \\
\text { Cytokines }\end{array}$} & $\mathrm{IFN}-\gamma$ & -0.01 & $-0.03,-0.001$ & 0.04 \\
\hline & IL-2 & -0.02 & $-0.04,-0.002$ & 0.03 \\
\hline & IL-2R§ & -0.005 & $-0.01,0.0003$ & 0.06 \\
\hline & IL-4 & -0.02 & $-0.03,-0.003$ & 0.02 \\
\hline & IL- 13 & -0.01 & $-0.02,-0.0004$ & 0.04 \\
\hline \multirow[t]{6}{*}{ Inflammation } & TNF- $\alpha$ & -0.01 & $-0.02,0.002$ & 0.11 \\
\hline & TNFRI§ & -0.001 & $-0.01,0.004$ & 0.72 \\
\hline & TNFRII§ & -0.001 & $-0.01,0.004$ & 0.83 \\
\hline & IL-I $\beta$ & -0.01 & $-0.02,0.01$ & 0.47 \\
\hline & IL-6 & -0.003 & $-0.01,0.01$ & 0.61 \\
\hline & IL-IO & -0.001 & $-0.01,0.004$ & $\mathrm{NE}^{*}$ \\
\hline \multirow[t]{6}{*}{ Growth Factors } & EGF & -0.01 & $-0.01,0.001$ & 0.09 \\
\hline & EGFR§ & 0.001 & $-0.001,0.003$ & 0.25 \\
\hline & FGF $\beta$ & $\mathrm{NE}^{*}$ & $\mathrm{NE}^{*}$ & $\mathrm{NE}^{*}$ \\
\hline & G-CSF & -0.003 & $-0.01,0.002$ & 0.28 \\
\hline & HGF & -0.002 & $-0.01,0.001$ & 0.20 \\
\hline & VEGF & $\mathrm{NE}^{*}$ & $\mathrm{NE}^{*}$ & $\mathrm{NE}^{*}$ \\
\hline
\end{tabular}

\footnotetext{
$\dagger \beta=$ regression co-efficient

$\ddagger \mathrm{p}=\mathrm{p}$-value

$\S$ For clarity, the soluble receptors are grouped with their respective ligand

*NE, Not Evaluable
}

temic corticosteroid use and statin use, three of the seven chemokines examined were significantly associated with $\% \mathrm{FEV}_{1}$ (Table 5). Increasing concentrations of chemokines CCL4/MIP-1 $\beta$, CCL2/MCP-1, and CCL11/eotaxin were associated with increasing severity of airflow obstruction. Of the $4 \mathrm{~T}_{\mathrm{H}}$ related cytokines that showed associations with \% FEV1 in univariate analysis (Table 4), only IL-13 remained significant (Table 5). Thus, CCL4/ MIP-1 $\beta$ and IL-13 showed inverse associations with \% FEV1 both by univariate and multivariate analysis.
Table 5: Association between plasma markers and \% FEV , adjusted*

\begin{tabular}{llll}
\hline Analyte & $\beta^{\dagger}$ & $95 \% \mathrm{Cl}$ & $\mathrm{P}^{\ddagger}$ \\
\hline CCL2/MCP -I & -0.003 & $-0.005,-0.001$ & 0.02 \\
CCL4/MIP-I $\beta$ & -0.01 & $-0.02,-0.001$ & 0.04 \\
CCLII/eotaxin & -0.005 & $-0.01,-0.002$ & 0.004 \\
CXCL9/Mig & -0.01 & $-0.02,0.0003$ & 0.06 \\
EGF & -0.005 & $-0.01,0.004$ & 0.24 \\
IFN- $\gamma$ & -0.01 & $-0.03,0.002$ & 0.08 \\
IL-2 & -0.02 & $-0.03,0.004$ & 0.12 \\
IL-2R & -0.005 & $-0.01,0.002$ & 0.15 \\
IL-4 & -0.02 & $-0.03,0.001$ & 0.07 \\
IL-I3 & -0.01 & $-0.02,-0.001$ & 0.04 \\
\hline
\end{tabular}

*Adjusted for current smoking, pack years, ICS use, SCS use, statin use, gender and age.

$\dagger \beta=$ regression co-efficient

$\ddagger p=p$-value

\section{Association between systemic cytokines and DLCO}

We examined the association between systemic cytokines and the $\%$ predicted DLCO (Table 6 ). Increasing concentrations of chemokines CCL4/MIP - $1 \beta$, CC chemokine ligand 5/Regulated on Activation Normal T cell Expressed and Secreted (CCL5/RANTES), CXC chemokine ligand 8/ interleukin 8 (CXCL8/IL-8), and CXCL9/Mig were associated with increasing severity of diffusion impairment, as characterized by decreasing \% predicted DLCO. Similar to $\mathrm{FEV}_{1}, \mathrm{~T}_{\mathrm{H}}$ related cytokines IFN- $\gamma$, IL-2, IL-4 and IL-13 showed inverse associations with the \% predicted DLCO. We also observed that increasing concentrations of TNF- $\alpha$, epidermal growth factor (EGF) and G-CSF associated with increasing severity of diffusion impairment. This is in contrast to soluble Fas where lower concentrations were associated with increasing severity of diffusion impairment. Systemic markers such as CRP, IL-6 and MPO did not show significant associations with the \% predicted DLCO.

\section{Multivariate model of the association between systemic cytokines and DLCO}

We further examined the relationship between plasma concentrations of inflammatory markers and the \% predicted DLCO, adjusting for the $\% \mathrm{FEV}_{1}$, age, gender, pack years smoking history, current smoking, inhaled corticosteroid use, systemic corticosteroid use and statin use (Table 7). The inverse associations between \% DLCO and CXCL9/Mig, G-CSF, and IL-13 remained significant. The association between soluble Fas and \% DLCO also remained significant.

\section{IL-I3 and Bronchodilator Reversiblity}

Of the 25 cytokines examined, increasing plasma concentrations of IL-13 showed inverse relationships with both $\% \mathrm{FEV}_{1}$ and \% DLCO (Figures 1 \&2). We tested the possibility that a subset of the population with bronchodilator 
reversibility may account for the inverse association between IL-13 and $\% \mathrm{FEV}_{1}$. Of those subjects with available information, 12 out of the 73 subjects in the cohort met ATS/ERS task force definition for bronchodilator response [44]. Excluding these 12 individuals did not alter the association between IL-13 and $\% \mathrm{FEV}_{1}(\beta=-0.01, \mathrm{p}=$ 0.01 ). An additional 15 out of the 73 subjects did not have bronchodilator reversibility testing at the time of study entry, although 10 of these subjects had emphysema by CT scan and/or abnormally low \% predicted DLCO. Further excluding these 15 individuals with unknown bronchodilator response from the cohort, the point estimates for the association between IL-13 and $\% \mathrm{FEV}_{1}$ in the remaining 46 subjects was essentially unchanged but did not reach significance due to greater variation $(\beta=-0.01$, $\mathrm{p}=0.06)$.

\section{Discussion}

We examined the association between 25 different plasma markers of inflammation and two physiologic parameters of COPD in a well-defined clinical population. The main observation was that increasing severity of airflow limitation, as defined by the $\% \mathrm{FEV}_{1}$, was associated with increasing systemic concentrations of IL-13, and the inflammatory chemokines CCL2/MCP-1, CCL4/MIP-1 $\beta$, and CCL11/eotaxin after adjusting for age, gender, pack years smoking history, current smoking, inhaled corticosteroid use, systemic corticosteroid use and statin use. Fur-

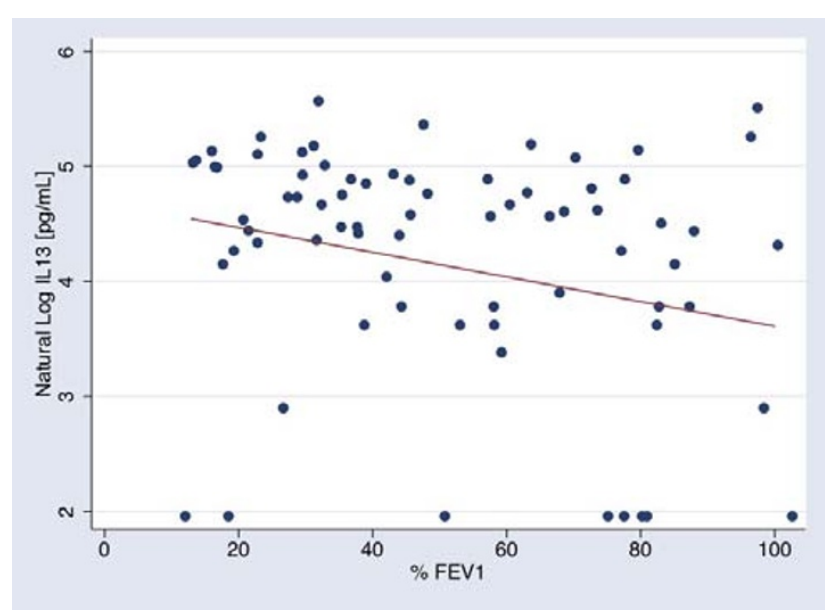

\section{Figure I}

The relationship between natural log (LN) IL-I 3 concentrations in $\mathrm{pg} / \mathrm{mL}$ and \% predicted FEVI. The line was calculated using conditional standardization of the regression results for a patient with mean and modal values for the covariates in the model. The standardized line thus represents the relationship between IL-I 3 and FEV, for a man, age 63, who does not currently smoke, with mean pack year smoking history of 52.5 years, who is not on statins or systemic steroids, but is on inhaled steroids $(\beta=-0.0 \mathrm{l})$.

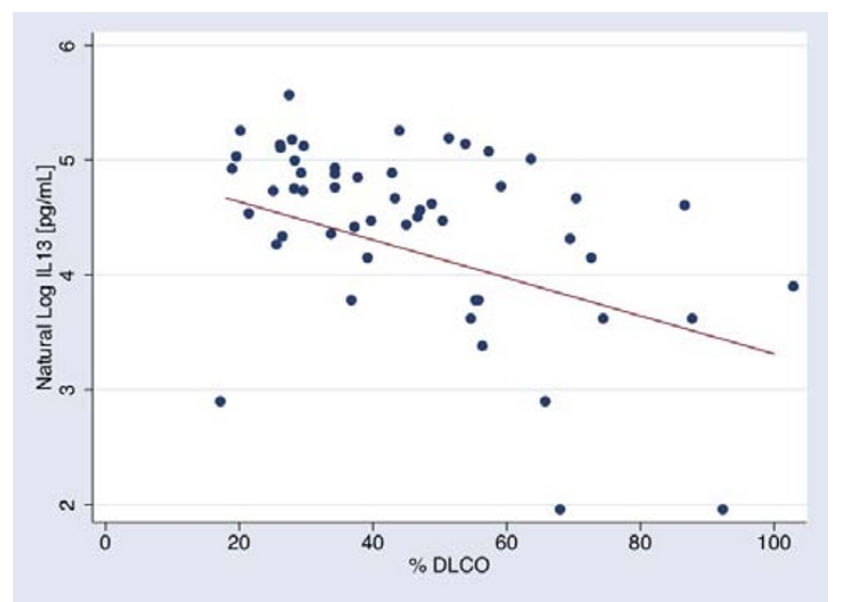

Figure 2

The relationship between natural log (LN) IL-I 3 concentrations in $\mathrm{pg} / \mathrm{mL}$ and \% predicted DLCO. The line was calculated using conditional standardization of the regression results for a patient with mean and modal values for the covariates in the model. The standardized line thus represents the relationship between IL- I 3 and DLCO for a man, age 63, with a $\mathrm{FEV}$, of $5 \mathrm{I} \%$ predicted, who does not currently smoke, with mean pack year smoking history of 52.5 years, who is not on statins or systemic steroids, but is on inhaled steroids $(\beta=-0.02)$.

thermore, increasing severity of diffusion impairment, as defined by the \% DLCO, was associated with increasing IL-13, CXCL9/Mig, and G-CSF concentrations and decreasing soluble Fas concentrations.

In both univariate and multivariate analysis, increasing plasma concentration of the $\mathrm{T}$ helper $2\left(\mathrm{~T}_{\mathrm{H} 2}\right)$ type cytokine IL-13 was associated with increasing severity of airflow obstruction, suggesting that IL-13 may be an important mediator in human COPD. The association between increasing IL-13 concentrations and increasing severity of airflow obstruction could not be accounted for by a subset of the cohort with bronchodilator reversibility. This finding suggests that the association is unlikely due to misclassification of asthmatic patients in our COPD cohort.

IL-13 is implicated in airway mucin production and airway inflammation $[45,46]$. IL-13 has been previously shown to induce mucous metaplasia and chemokine expression in animal models of allergic airway inflammation and emphysema $[47,48]$. Others have recently shown that both $\mathrm{CD}^{+}$and $\mathrm{CD} 8^{+} \mathrm{T}$ cells in the bronchoalveolar lavage fluid of COPD patients expressed significantly higher percentages of IL-13 than smokers with normal lung function and never smokers [28]. Similar to our find- 
Table 6: Association between plasma marker concentrations and $\%$ DLCO, unadjusted

\begin{tabular}{|c|c|c|c|c|}
\hline Classification & $\begin{array}{l}\text { Plasma } \\
\text { marker }\end{array}$ & $\beta^{\dagger}$ & $95 \% \mathrm{Cl}$ & $\mathrm{p}^{\ddagger}$ \\
\hline \multirow[t]{2}{*}{ Apoptosis } & Fas & 0.01 & $0.001,0.01$ & 0.01 \\
\hline & FasL & -0.0004 & $-0.007,0.006$ & 0.89 \\
\hline \multirow[t]{2}{*}{ Acute phase } & CRP & -0.01 & $-0.02,0.01$ & 0.33 \\
\hline & MPO & -0.005 & $-0.01,0.004$ & 0.30 \\
\hline \multirow[t]{7}{*}{ Chemokines } & CCL2/MCP - I & -0.003 & $-0.01,0.0004$ & 0.09 \\
\hline & CCL3/MIP-I $\alpha$ & 0.001 & $-0.02,0.02$ & 0.92 \\
\hline & CCL4/MIP-I $\beta$ & -0.02 & $-0.03,-0.001$ & 0.04 \\
\hline & $\begin{array}{l}\text { CCL5/ } \\
\text { RANTES }\end{array}$ & -0.01 & $-0.02,-0.002$ & 0.02 \\
\hline & $\begin{array}{l}\text { CCLII/ } \\
\text { eotaxin }\end{array}$ & -0.002 & $-0.01,0.002$ & 0.31 \\
\hline & CXCL8/IL-8 & -0.005 & $-0.01,-0.002$ & $<0.01$ \\
\hline & CXCL9/Mig & -0.01 & $-0.02,-0.004$ & $<0.01$ \\
\hline \multirow[t]{5}{*}{$\begin{array}{l}\mathbf{T}_{\mathrm{H}} \text { Related } \\
\text { Cytokines }\end{array}$} & $\mathrm{IFN}-\gamma$ & -0.03 & $-0.04,-0.01$ & $\begin{array}{l}< \\
0.001\end{array}$ \\
\hline & $\mathrm{IL}-2$ & -0.04 & $-0.06,-0.02$ & $<0.01$ \\
\hline & $\mathrm{IL}-2 \mathrm{R}^{\S}$ & -0.005 & $-0.01,0.002$ & 0.18 \\
\hline & $\mathrm{IL}-4$ & -0.03 & $-0.06,-0.01$ & $<0.01$ \\
\hline & IL-I3 & -0.02 & $-0.03,-0.01$ & $\begin{array}{l}< \\
0.001\end{array}$ \\
\hline \multirow[t]{6}{*}{ Inflammation } & TNF- $\alpha$ & -0.02 & $-0.03,-0.005$ & $<0.01$ \\
\hline & TNFRI§ & 0.001 & $-0.01,0.01$ & 0.79 \\
\hline & TNFRII§ & 0.001 & $-0.004,0.005$ & 0.84 \\
\hline & IL-I $\beta$ & -0.01 & $-0.03,0.004$ & 0.13 \\
\hline & IL-6 & -0.01 & $-0.02,0.004$ & 0.17 \\
\hline & IL-10 & -0.01 & $-0.01,0.003$ & $\mathrm{NE}^{*}$ \\
\hline \multirow{6}{*}{$\begin{array}{l}\text { Growth } \\
\text { Factors }\end{array}$} & EGF & -0.01 & $-0.02,0.0001$ & 0.05 \\
\hline & EGFR§ & 0.002 & $-0.001,0.005$ & 0.12 \\
\hline & FGF $\beta$ & $\mathrm{NE}^{*}$ & $\mathrm{NE}^{*}$ & $\mathrm{NE}^{*}$ \\
\hline & G-CSF & -0.01 & $-0.02,-0.002$ & 0.02 \\
\hline & $\mathrm{HGF}$ & -0.005 & $-0.01,0.001$ & 0.08 \\
\hline & VEGF & NE* & $\mathrm{NE}^{*}$ & $\mathrm{NE}^{*}$ \\
\hline
\end{tabular}

$\dagger \beta=$ regression co-efficient

$\ddagger \mathrm{p}=\mathrm{p}$-value

$\S$ For clarity, the soluble receptors are grouped with their respective ligand

*NE, Not Evaluable

ings, these authors showed a negative correlation between intracellular IL-13 and \% $\mathrm{FEV}_{1}$.

Three of seven chemokines tested were associated with increasing severity of airflow obstruction: CCL2/MCP-1, CCL4/MIP-1 $\beta$, and CCL11/Eotaxin. In addition, CXCL9/ Mig was associated with increasing severity of diffusion impairment. These chemokines recruit primarily monocytes, T lymphocytes, and eosinophils, inviting the possibility that soluble proteins that promote inflammatory cell recruitment contribute to the low-grade systemic inflammation observed in COPD. CCL2/MCP-1 recruits monocytes and $\mathrm{T}$ lymphocytes expressing the receptor CCR2 [49], and increased concentrations of this chemokine have been reported in induced sputum, BAL and lung
Table 7: Association between plasma markers and \% DLCO, adjusted*

\begin{tabular}{llll}
\hline Analyte & $\beta^{\dagger}$ & $95 \% \mathrm{Cl}$ & $\mathrm{P}^{\ddagger}$ \\
\hline CCL2/MCP-I & -0.001 & $-0.01,0.003$ & 0.58 \\
CCL4/MIP-I $\beta$ & 0.004 & $-0.02,0.03$ & 0.76 \\
CCL5/RANTES & -0.01 & $-0.03,0.003$ & 0.11 \\
CCLII/eotaxin & -0.005 & $-0.01,0.002$ & 0.15 \\
CXCL8/IL-8 & -0.004 & $-0.01,0.002$ & 0.18 \\
CXCL9/Mig & -0.02 & $-0.03,-0.002$ & 0.02 \\
EGF & -0.01 & $-0.03,0.01$ & 0.29 \\
Fas & 0.01 & $0.003,0.02$ & 0.01 \\
G-CSF & -0.01 & $-0.02,-0.0001$ & 0.05 \\
HGF & -0.0001 & $-0.01,0.01$ & 0.99 \\
IFN- $\gamma$ & -0.02 & $-0.05,0.01$ & 0.11 \\
IL-2 & -0.03 & $-0.06,0.01$ & 0.11 \\
IL-2R & 0.01 & $-0.01,0.02$ & 0.46 \\
IL-4 & -0.02 & $-0.05,0.02$ & 0.30 \\
IL-I3 & -0.02 & $-0.03,-0.002$ & 0.03 \\
TNF- $\alpha$ & -0.01 & $-0.03,0.003$ & 0.11 \\
\end{tabular}

*Adjusted for \% FEVI, current smoking, pack years, ICS use, SCS use, statin use, gender and age.

$\dagger \beta=$ regression co-efficient

$\neq \mathrm{p}=\mathrm{p}$-value

tissue of COPD individuals [38,50]. CCL4/MIP-1 $\beta$ can recruit CCR5 expressing monocytes and Tymphocytes [49]. Our data corroborates findings showing a negative correlation between CCL4/MIP-1 $\beta$ concentrations in the BAL from patients with chronic bronchitis and the $\% \mathrm{FEV}_{1}$ [21]. CCL11/Eotaxin is involved in eosinophil recruitment [51], and CCL11/eotaxin concentrations are increased in the sputum of patients with exacerbations of chronic bronchitis [23]. However, some COPD patients with stable disease also show airway eosinophilic inflammation [52].

A secondary goal of this study was to explore whether systemic cytokines are associated with severity of diffusion impairment, the physiologic parameter that corresponds best to the loss of alveolar-capillary bed surface area in emphysema. In the smaller cohort that received DLCO measurements, it is interesting that CXCL9/Mig concentration was inversely associated with \% DLCO. CXCL9/ Mig recruits CXCR3 expressing T lymphocytes [49]. Saetta and colleagues have previously shown increased numbers of CXCR3 expressing T lymphocytes in peripheral airways of COPD patients [53]. Upon stimulation with CXCL9/ Mig, CD14+ CXCR3+ macrophages of human emphysematous lungs can increase metalloproteinase production in vitro [26]. Thus, recent findings suggest a potential link between this chemokine and the pro-elastolytic environment \# of emphysema.

Increasing concentrations of plasma G-CSF are also associated with increasing severity of diffusion impairment. GCSF is involved in neutrophil mobilization and survival 
[54], however its role in COPD is not yet known. There are increased numbers of granulocytes in the sputum and BAL [38] in addition to small airways [55] of COPD patients, leading others to speculate that granulocyte survival in the lungs may be enhanced in COPD by mediators such as GCSF [38].

Another molecule identified is soluble Fas. Decreasing concentrations of soluble Fas are associated with increasing severity of diffusion impairment. Soluble Fas, a result of alternative mRNA splicing, inhibits apoptosis by competitively binding FasL and preventing its interaction with the membrane bound Fas receptor [56,57]. The relationship between systemic levels of soluble Fas and COPD is unclear, as other smaller studies have shown variable findings of either elevation or no difference compared with controls [17-19]. Our results suggests that a systemic imbalance of the anti-apoptotic factor soluble Fas occurs in the setting of a pro-apoptotic environment of the lungs in COPD.

The limitations of this present study include the size of the cohort and its cross-sectional nature. The modest size, particularly the number of subjects with milder lung function impairment (GOLD 0-1 stages), may limit the ability to detect significant associations between systemic markers and lung function impairment. Furthermore, we included age, gender, pack years smoking history, current smoking, inhaled corticosteroid use, systemic corticosteroid use and statin use in the multivariate model. It is uncertain whether adjustment for these covariates is appropriate. Thus, we present both univariate and multivariate analysis. We also recognize that the observed associations between plasma concentrations of a protein and lung function severity do not necessarily invoke a cause-effect relationship. However, the findings of this study can serve as the basis for a larger prospective cohort study examining a narrower profile of cytokines on a longitudinal basis.

\section{Conclusion}

Systemic inflammation has been increasingly recognized in patients with COPD. CRP has been shown to be increased in COPD [3,4], yet many other disease states characterized by inflammation are associated with increased CRP concentrations. Our data suggests that systemic inflammation in a COPD cohort is also characterized by cytokines implicated in inflammatory cell recruitment and airway remodeling. We show associations between plasma concentrations of chemokines and IL-13 with increasing severity of disease, as measured by $\% \mathrm{FEV}_{1}$ or $\%$ DLCO. Increasing severity of diffusion impairment is also associated with increasing G-CSF and decreasing soluble Fas concentrations. We speculate that disease characterized by disproportionate abnormalities in DLCO may be associated with peripheral markers inde- pendent of the $\mathrm{FEV}_{1}$. The biological plausibility of IL-13 and the discrete repertoire of inflammatory chemokines identified in our model underscore the possibility to more precisely characterize systemic inflammation of COPD.

\section{Abbreviations}

CCL2/MCP-1, CC chemokine ligand 2/monocyte chemotattractant protein-1; CCL3/MIP-1 $\alpha$, CC chemokine ligand $3 /$ macrophage inflammatory protein- $1 \alpha$; CCL4/MIP$1 \beta$, CC chemokine ligand 4/macrophage inflammatory protein-1 $\beta$; CCL5/RANTES, CC chemokine ligand 5/regulated on activation normal $\mathrm{T}$ cell expressed and secreted; CCL11/eotaxin, CC chemokine ligand 11/eotaxin; CRP, C-reactive protein; CXCL8/IL-8, CXC chemokine ligand 8/ interleukin-8; CXCL9/Mig, CXC chemokine ligand 9/ monkine induced by interferon- $\gamma$; EGF, epidermal growth factor; EGFR, epidermal growth factor receptor; FasL, Fas ligand; FGF $\beta$, fibroblast growth factor $\beta$; G-CSF, granulocyte-colony stimulating factor; HGF, hepatocyte growth factor; IFN- $\gamma$, interferon- $\gamma$; IL-1 $\beta$, interleukin- $1 \beta$; IL-2, interleukin-2; IL-2R, interleukin-2 receptor; IL-4, interleukin-4, IL-6, interleukin-6; IL-10, interleukin-10; IL-13, interleukin-13; MPO, myeloperoxidase; TNF- $\alpha$, tumor necrosis factor $\alpha$, TNFRI, tumor necrosis factor receptor 1 , TNFRII, tumor necrosis factor receptor 2; VEGF, vascular endothelial growth factor;

\section{Competing interests}

Frank C. Sciurba has received funding from GlaxoSmithKline and AstraZeneca in 2005 through 2006 for participation in multi-center clinical trials. He has served on advisory boards for GlaxoSmithKline and AstraZeneca. None of the other authors has any competing interests to declare.

\section{Authors' contributions}

JSL, VK, YZ, JM, RAB, AMC and FCS participated in the design of the study. JSL contributed to the statistical analysis, interpretation of the data, and wrote the manuscript. MRR performed portions of the statistical analysis, contributed to the interpretation of the data, and revised the manuscript for important intellectual content. VK performed the statistical analysis. YZ participated in the collection of data. JM participated in the analysis of the data. $\mathrm{RAB}$ contributed to the analysis and interpretation of data, and revised the manuscript for important intellectual content. AMC and FCS conceived the study, contributed to the acquisition of the data, and provided important intellectual content to the manuscript. All authors read and approved the final manuscript.

\section{Acknowledgements}

We gratefully acknowledge Naftali Kaminiski for his assistance in facilitating the performance of luminex assays at the University of Pittsburgh Cancer Institute Luminex Core Facility and for selection of some of the plasma markers studied. We also thank Anna Loshkin, Director of the University 
of Pittsburgh Cancer Insitute Luminex Core Facility, for her help in the performance of the assays. We gratefully acknowledge Bill Slivka, Chad Karoleski, Denise Filippino, Mary Bryner for their assistance with the pulmonary function testing, data entry, and clinical recruitment of patients. We are deeply indebted to the participants of the ECRC registry.

This study was supported by the ATS Research Grant Innovative Research in COPD (JSL), HL70 78 (JSL), General Clinical Research Grant No. 5 MOI RR 0056 (RAB), HL084948 (FCS).

\section{References}

I. Pauwels RA, Buist AS, Calverley PM, Jenkins CR, Hurd SS: Global strategy for the diagnosis, management, and prevention of chronic obstructive pulmonary disease. NHLBI/WHO Global Initiative for Chronic Obstructive Lung Disease (GOLD) Workshop summary. Am J Respir Crit Care Med 200I, 163(5): | 256-1276.

2. Rabe K, Barnes P, Buist S, Calverley PM, Fabbri L, Fukuchi Y, MacNee W, Rodriguez-Roisin R, Zielinski I: Global Strategy for the Diagnosis, Management, and Prevention of Chronic Obstructive Pulmonary Disease. NHLBI/WHO Global Initiative for Chronic Obstructive Lung Disease Workshop Executive Summary, 2005 Update. GOLD website wwwgoldcopdorg 2005.

3. Gan WQ, Man SF, Senthilselvan A, Sin DD: Association between chronic obstructive pulmonary disease and systemic inflammation: a systematic review and a meta-analysis. Thorax 2004 , 59(7):574-580.

4. Mannino DM, Ford ES, Redd SC: Obstructive and restrictive lung disease and markers of inflammation: data from the Third National Health and Nutrition Examination. Am J Med 2003, I I 4(9):758-762.

5. Gan WQ, Man SF, Sin DD: The interactions between cigarette smoking and reduced lung function on systemic inflammation. Chest 2005, 127(2):558-564.

6. Man SF, Sin DD: Effects of corticosteroids on systemic inflammation in chronic obstructive pulmonary disease. Proc $\mathrm{Am}$ Thorac Soc 2005, 2(I):78-82.

7. Sin DD, Lacy P, York E, Man SF: Effects of fluticasone on systemic markers of inflammation in chronic obstructive pulmonary disease. Am J Respir Crit Care Med 2004, I 70(7):760-765.

8. Lung function testing: selection of reference values and interpretative strategies. American Thoracic Society. Am Rev Respir Dis 1991, 144(5): 1202-1218.

9. Standardization of Spirometry, 1994 Update. American Thoracic Society. Am J Respir Crit Care Med 1995, I 52(3): I 107-I I36.

10. Miller MR, Hankinson J, Brusasco V, Burgos F, Casaburi R, Coates A, Crapo R, Enright $P$, van der Grinten $C P$, Gustafsson $P$, Jensen R, Johnson DC, Maclntyre N, McKay R, Navajas D, Pedersen OF, Pellegrino R, Viegi G, Wanger J: Standardisation of spirometry. Eur Respir J 2005, 26(2):319-338.

II. Macintyre N, Crapo RO, Viegi G, Johnson DC, van der Grinten CP, Brusasco V, Burgos F, Casaburi R, Coates A, Enright P, Gustafsson P, Hankinson J, Jensen R, McKay R, Miller MR, Navajas D, Pedersen OF, Pellegrino R, Wanger J: Standardisation of the single-breath determination of carbon monoxide uptake in the lung. Eur Respir J 2005, 26(4):720-735.

12. Crapo RO, Morris AH: Standardized single breath normal values for carbon monoxide diffusing capacity. Am Rev Respir Dis | 98I, I 23(2): 185-189.

13. Crapo RO, Morris AH, Gardner RM: Reference spirometric values using techniques and equipment that meet ATS recommendations. Am Rev Respir Dis 198I, I 23(6):659-664.

14. Gorelik E, Landsittel DP, Marrangoni AM, Modugno F, Velikokhatnaya L, Winans MT, Bigbee WL, Herberman RB, Lokshin AE: Multiplexed immunobead-based cytokine profiling for early detection of ovarian cancer. Cancer Epidemiol Biomarkers Prev 2005, I 4(4):98I-987.

15. Lee JS, Wurfel MM, Matute-Bello G, Frevert CW, Rosengart MR, Ranganathan M, Wong VW, Holden T, Sutlief S, Richmond A, Peiper S, Martin TR: The Duffy antigen modifies systemic and local tissue chemokine responses following lipopolysaccharide stimulation. J Immunol 2006, I77( I I):8086-8094.
16. Wurfel MM, Park WY, Radella F, Ruzinski J, Sandstrom A, Strout J, Bumgarner RE, Martin TR: Identification of high and low responders to lipopolysaccharide in normal subjects: an unbiased approach to identify modulators of innate immunity. J Immunol 2005, I 75(4):2570-2578.

17. Yasuda N, Gotoh K, Minatoguchi S, Asano K, Nishigaki K, Nomura M, Ohno A, Watanabe M, Sano H, Kumada H, Sawa T, Fujiwara H: An increase of soluble Fas, an inhibitor of apoptosis, associated with progression of COPD. Respir Med 1998, 92(8):993-999.

18. Takabatake N, Arao T, Sata M, Inoue S, Abe S, Shibata Y, Kubota I: Circulating levels of soluble Fas ligand in cachexic patients with COPD are higher than those in non-cachexic patients with COPD. Intern Med 2005, 44(I I): I I37-I I 43.

19. Takabatake N, Nakamura H, Inoue S, Terashita K, Yuki H, Kato S, Yasumura S, Tomoike H: Circulating levels of soluble Fas ligand and soluble Fas in patients with chronic obstructive pulmonary disease. Respir Med 2000, 94( I 2): 12 15-1220.

20. Andelid K, Bake B, Rak S, Linden A, Rosengren A, Ekberg-Jansson A: Myeloperoxidase as a marker of increasing systemic inflammation in smokers without severe airway symptoms . Respir Med 2007, 101:888-895 2007, 101:888-95.

21. Capelli A, Di Stefano A, Gnemmi I, Balbo P, Cerutti CG, Balbi B, Lusuardi M, Donner CF: Increased MCP-I and MIP-Ibeta in bronchoalveolar lavage fluid of chronic bronchitics. Eur Respir J 1999, I4(I): 160-165.

22. Zhu J, Qiu YS, Majumdar S, Gamble E, Matin D, Turato G, Fabbri LM, Barnes N, Saetta M, Jeffery PK: Exacerbations of Bronchitis: bronchial eosinophilia and gene expression for interleukin-4, interleukin-5, and eosinophil chemoattractants. Am J Respir Crit Care Med 200 I, 164(1):109-II6.

23. Bocchino V, Bertorelli G, Bertrand CP, Ponath PD, Newman W, Franco C, Marruchella A, Merlini S, Del Donno M, Zhuo X, Olivieri $D$ : Eotaxin and CCR3 are up-regulated in exacerbations of chronic bronchitis. Allergy 2002, 57(I): 17-22.

24. Nocker RE, Schoonbrood DF, van de Graaf EA, Hack CE, Lutter R, jansen HM, Out TA: Interleukin-8 in airway inflammation in patients with asthma and chronic obstructive pulmonary disease. Int Arch Allergy Immunol 1996, 109(2): I83-191.

25. Tanino M, Betsuyaku T, Takeyabu K, Tanino Y, Yamaguchi E, Miyamoto K, Nishimura M: Increased levels of interleukin-8 in BAL fluid from smokers susceptible to pulmonary emphysema. Thorax 2002, 57(5):405-4II.

26. Grumelli S, Corry DB, Song LZ, Song L, Green L, Huh J, Hacken J, Espada R, Bag R, Lewis DE, Kheradmand F: An immune basis for lung parenchymal destruction in chronic obstructive pulmonary disease and emphysema. PLoS Med 2004, I (I):e8.

27. Elias JA, Kang MJ, Crouthers K, Homer R, Lee CG: State of the art. Mechanistic heterogeneity in chronic obstructive pulmonary disease: insights from transgenic mice. Proc Am Thorac Soc 2006, 3(6):494-498.

28. Barcelo B, Pons J, Fuster A, Sauleda J, Noguera A, Ferrer JM, Agusti AG: Intracellular cytokine profile of $T$ lymphocytes in patients with chronic obstructive pulmonary disease. Clin Exp Immunol 2006, 145(3):474-479.

29. Barnes PJ, Cosio MG: Characterization of $\mathbf{T}$ lymphocytes in chronic obstructive pulmonary disease. PLoS Med 2004, I(I):e20.

30. Eid AA, lonescu AA, Nixon LS, Lewis-Jenkins V, Matthews SB, Griffiths TL, Shale DJ: Inflammatory response and body composition in chronic obstructive pulmonary disease. Am J Respir Crit Care Med 200I, 164(8 Pt I): |4| 4-| $4 \mid 8$.

3I. Vernooy JH, Kucukaycan M, Jacobs JA, Chavannes NH, Buurman WA, Dentener MA, Wouters EF: Local and systemic inflammation in patients with chronic obstructive pulmonary disease: soluble tumor necrosis factor receptors are increased in sputum. Am J Respir Crit Care Med 2002, I66(9): 12 I 8-1224.

32. Ferroni P, Basili S, Alessandri C, Vieri M, Martini F, Belogi A, Pulcinelli FM, Cordova C, Gazzaniga PP: Proinflammatory cytokines and hemostatic system in patients with chronic obstructive pulmonary disease. Platelets 1997, 8(4):255-259.

33. Takeyama K, Jung B, Shim JJ, Burgel PR, Dao-Pick T, Ueki IF, Protin U, Kroschel P, Nadel JA: Activation of epidermal growth factor receptors is responsible for mucin synthesis induced by cigarette smoke. Am J Physiol Lung Cell Mol Physiol 200I, 280(I):LI65-72. 
34. Nadel JA: Role of epidermal growth factor receptor activation in regulating mucin synthesis. Respir Res 200I, 2(2):85-89.

35. Nadel JA, Burgel PR: The role of epidermal growth factor in mucus production. Curr Opin Pharmacol 200I, I(3):254-258.

36. Kranenburg AR, De Boer WI, Van Krieken JH, Mooi WJ, Walters JE, Saxena PR, Sterk PJ, Sharma HS: Enhanced expression of fibroblast growth factors and receptor FGFR-I during vascular remodeling in chronic obstructive pulmonary disease. $\mathrm{Am} J$ Respir Cell Mol Biol 2002, 27(5):5 I7-525.

37. Kranenburg AR, Willems-Widyastuti A, Mooi WJ, Saxena PR, Sterk PJ, de Boer WI, Sharma HS: Chronic obstructive pulmonary disease is associated with enhanced bronchial expression of FGF-I, FGF-2, and FGFR-I. J Pathol 2005, 206(I):28-38.

38. Barnes PJ: Mediators of chronic obstructive pulmonary disease. Pharmacol Rev 2004, 56(4):5 I5-548.

39. Plantier L, Marchand-Adam S, Marchal-Somme J, Leseche G, Fournier M, Dehoux M, Aubier M, Crestani B: Defect of hepatocyte growth factor production by fibroblasts in human pulmonary emphysema. Am J Physiol Lung Cell Mol Physiol 2005, 288(4):L64 I-7.

40. Kasahara $Y$, Tuder RM, Taraseviciene-Stewart L, Le Cras TD, Abman S, Hirth PK, Waltenberger J, Voelkel NF: Inhibition of VEGF receptors causes lung cell apoptosis and emphysema. J Clin Invest 2000, 106(II):1311-1319.

41. Bio-Rad Laboratories I: Principles of Curve Fitting for Multiplex Sandwich Immunoassays, Rev. B, Bulletin \# 286 I. wwwbio-radcom .

42. de Jager W, Rijkers GT: Solid-phase and bead-based cytokine immunoassay: a comparison. Methods 2006, 38(4):294-303.

43. Hurst JR, Donaldson GC, Perera WR, Wilkinson TM, Bilello JA, Hagan GW, Vessey RS, Wedzicha JA: Use of plasma biomarkers at exacerbation of chronic obstructive pulmonary disease. Am J Respir Crit Care Med 2006, I 74(8):867-874.

44. Pellegrino R, Viegi G, Brusasco V, Crapo RO, Burgos F, Casaburi R, Coates A, van der Grinten CP, Gustafsson P, Hankinson J, Jensen R, Johnson DC, Maclntyre N, McKay R, Miller MR, Navajas D, Pedersen $\mathrm{OF}$, Wanger J: Interpretative strategies for lung function tests. Eur Respir J 2005, 26(5):948-968.

45. Shim JJ, Dabbagh K, Ueki IF, Dao-Pick T, Burgel PR, Takeyama K, Tam DC, Nadel JA: IL- 13 induces mucin production by stimulating epidermal growth factor receptors and by activating neutrophils. Am J Physiol Lung Cell Mol Physiol 200I, 280( I):LI34-40.

46. Ma B, Liu W, Homer RJ, Lee PJ, Coyle AJ, Lora JM, Lee CG, Elias JA: Role of CCR5 in the pathogenesis of IL-13-induced inflammation and remodeling. J Immunol 2006, I 76(8):4968-4978.

47. Zhu Z, Homer RJ, Wang Z, Chen Q, Geba GP, Wang J, Zhang Y, Elias $J A$ : Pulmonary expression of interleukin- $I 3$ causes inflammation, mucus hypersecretion, subepithelial fibrosis, physiologic abnormalities, and eotaxin production. J Clin Invest 1999, 103(6):779-788.

48. Zheng T, Zhu Z, Wang Z, Homer RJ, Ma B, Riese RJ Jr., Chapman HA Jr., Shapiro SD, Elias JA: Inducible targeting of IL-I 3 to the adult lung causes matrix metalloproteinase- and cathepsindependent emphysema. J Clin Invest 2000, 106(9): 108I-1093.

49. Murphy PM, Baggiolini M, Charo IF, Hebert CA, Horuk R, Matsushima $\mathrm{K}$, Miller LH, Oppenheim JJ, Power CA: International union of pharmacology. XXII. Nomenclature for chemokine receptors. Pharmacol Rev 2000, 52(I): I 45-176.

50. Traves SL, Culpitt SV, Russell RE, Barnes PJ, Donnelly LE: Increased levels of the chemokines GROalpha and MCP-I in sputum samples from patients with COPD. Thorax 2002, 57(7):590-595.

5I. Fukakusa M, Bergeron C, Tulic MK, Fiset PO, Al Dewachi O, Laviolette M, Hamid Q, Chakir J: Oral corticosteroids decrease eosinophil and CC chemokine expression but increase neutrophil, IL-8, and IFN-gamma-inducible protein 10 expression in asthmatic airway mucosa. J Allergy Clin Immunol 2005, I I 5(2):280-286.

52. Brightling CE, Monteiro W, Ward R, Parker D, Morgan MD, Wardlaw A], Pavord ID: Sputum eosinophilia and short-term response to prednisolone in chronic obstructive pulmonary disease: a randomised controlled trial. Lancet 2000, 356(9240): I 480-I 485.

53. Saetta M, Mariani M, Panina-Bordignon P, Turato G, Buonsanti C, Baraldo S, Bellettato CM, Papi A, Corbetta L, Zuin R, Sinigaglia F, Fabbri LM: Increased expression of the chemokine receptor CXCR3 and its ligand CXCLIO in peripheral airways of smokers with chronic obstructive pulmonary disease. Am J Respir Crit Care Med 2002, 165(10): I404-1409.

54. Colotta F, Re F, Polentarutti N, Sozzani S, Mantovani A: Modulation of granulocyte survival and programmed cell death by cytokines and bacterial products. Blood 1992, 80(8):2012-2020.

55. Hogg JC, Chu F, Utokaparch S, Woods R, Elliott WM, Buzatu L, Cherniack RM, Rogers RM, Sciurba FC, Coxson HO, Pare PD: The nature of small-airway obstruction in chronic obstructive pulmonary disease. N Engl J Med 2004, 350(26):2645-2653.

56. Albertine KH, Soulier MF, Wang Z, Ishizaka A, Hashimoto S, Zimmerman GA, Matthay MA, Ware LB: Fas and fas ligand are up-regulated in pulmonary edema fluid and lung tissue of patients with acute lung injury and the acute respiratory distress syndrome. Am J Pathol 2002, I6 I(5): 1783-1796.

57. Cheng J, Zhou T, Liu C, Shapiro JP, Brauer MJ, Kiefer MC, Barr PJ, Mountz JD: Protection from Fas-mediated apoptosis by a soluble form of the Fas molecule. Science 1994, 263(5 I54): 1759-1762.
Publish with Biomed Central and every scientist can read your work free of charge

"BioMed Central will be the most significant development for disseminating the results of biomedical research in our lifetime. "

Sir Paul Nurse, Cancer Research UK

Your research papers will be:

- available free of charge to the entire biomedical community

- peer reviewed and published immediately upon acceptance

- cited in PubMed and archived on PubMed Central

- yours - you keep the copyright

Submit your manuscript here:

http://www.biomedcentral.com/info/publishing_adv.asp
BioMedcentral 